\title{
PENGARUH KUALITAS PELAYANAN TERHADAP KEPUASAN KONSUMEN PADA PT TRIJAYA LESTARI DI JAKARTA
}

\author{
${ }^{1}$ Kusnadi, ${ }^{2 *}$ Ruknan \\ Universitas Pamulang, Tangerang Selatan, Banten, Indonesia \\ 1kusnadi.se76@gmail.com, $2^{2 *}$ osen01757@unpam.ac.id
}

\begin{abstract}
Abstrak
Penelitian ini bertujuan untuk mengetahui pengaruh kualitas pelayanan terhadap kepuasan konsumen pada PT. Trijaya Lestari di Jakarta. Metode yang digunakan adalah explanatory research dengan sampel sebanyak 100 responden. Teknik analisis menggunakan analisis statistik dengan pengujian regresi, korelasi, determinasi dan uji hipotesis. Hasil penelitian ini variabel kualitas pelayanan diperoleh nilai rata-rata skor sebesar 3,420 dengan kriteria baik. Variabel kepuasan konsumen diperoleh nilai rata-rata skor sebesar 3,837 dengan kriteria baik. Kualitas pelayanan berpengaruh positif dan signifikan terhadap kepuasan konsumen dengan nilai persamaan regresi $Y=$ $8,237+0,881 \mathrm{X}$, dan nilai koefisien korelasi 0,788 atau memiliki tingkat hubungan yang kuat dengan nilai determinasi $62,1 \%$. Uji hipotesis diperoleh signifikansi $0,000<0,05$.
\end{abstract}

Kata Kunci: Kualitas Pelayanan, Kepuasan Konsumen

Abstract

This study aims to determine the effect of service quality on customer satisfaction at PT. Trijaya Lestari in Jakarta. The method used is explanatory research with a sample of 100 respondents. The analysis technique uses statistical analysis with regression, correlation, determination and hypothesis testing. The results of this study of service quality variables obtained an average score of 3,420 with good criteria. The consumer satisfaction variable obtained an average score of 3.837 with good criteria. Service quality has a positive and significant effect on customer satisfaction with the value of the regression equation $Y=8.237+0.881 X$, and the correlation coefficient value of 0.788 or has a strong relationship with a determination value of $62.1 \%$. Hypothesis testing obtained a significance of $0.000<0.05$.

Keywords: Service Quality, Consumer Satisfaction

\section{PENDAHULUAN}

Pada era globalisasi ini perkembangan ilmu pengetahuan dan teknologi semakin maju. hal ini mendorong perkembangan dunia usaha yang semakin pesat dan persaingan pasar semakin pesat, dan persaingan para pengusaha semakin ketat sehingga menuntut adanya sistem pemasaran yang semakin baik pada setiap perusahaan yang bergerak dibidang industri maupun jasa.

Pemasaran merupakan salah satu sarana bagi perusahaan untuk mencapai tujuan yang telah ditetapkan perusahaan. Agar tujuan tersebut tecapai maka setiap perusahaan harus berupaya menghasilkan dan menyampaikan harga barang atau jasa yang diinginkan konsumen dengan memberikan pelayanan yang menyenangkan sehingga membuat para konsumen merasa nyaman.

Memberikan pelayanan yang unggul merupakan sebuah strategi yang sangat penting karena dapat menghasilkan lebih banyak pelanggan baru. Pelayanan merupakan komponen nilai yang pokok yang menggerakan setiap perusahaan untuk sukses. Perusahaan yang ingin berkembang dan mendapatkan keunggulan yang kompetitif harus dapat memberikan produk berupa barang atau jasa yang berkualitas dengan harga murah dan pelayanan yang baik kepada konsumen dari para pesaing untuk memenuhi kepuasan konsumen, kualitas pelayanan penting dikelola perusahaan dengan baik. 
Kualitas pelayanan sangat penting bagi suatu pusahaan, kualitas pelayanan terbaik merupakan suatu profit strategi untuk meningkatkan lebih banyak pelanggan baru, mempertahankan pelanggan yang ada, menghindari kaburnya pelanggan, dan menciptakan keunggulan yang tidak hanya bersaing dari segi harga. Apabila pelayanan yang diterima atau dirasa sesuai dengan yang diharapkan oleh pelanggan, maka kualitas pelayanan dapat dipersepsikan baik dan memuaskan. Pelayanan adalah segala bentuk aktivitas yang dilakukan oleh suatu perusahaan guna memenuhi harapan konsumen. Kualitas akan mendorong konsumen untuk menjalin hubungan erat dengan perusahaan. Dalam jangka panjang, ikatan ini memungkinkan perusahaan untuk memahami harapan dan kebutuhan kosumen. Kepuasaan konsumen pada akhirnya akan menciptakan loyalitas konsumen kepada perusahaan yang memberikan kualitas yang memuaskan para konsumen. Pelayanan konsumen tidak hanya sekedar menjawab pertanyaan dan keluhan konsumen mengenai produk atau jasa yang tidak memuaskan mereka, namun lebih dari pemecahan yang timbul setelah pembelian.

Kualitas pelayanan merupakan sebagai upaya pemenuhan kebutuhan dan keiginan konsumen serta ketepatan penyampaiannya dalam mengimbangi harapan konsumen. Definisi pelayanan menurut Kotler (2018: 83) adalah setiap tindakan atau kegiatan yang dapat ditawarkan oleh suatu pihak ke pihak lain, yang pada dasarnya tidak berwujud dan tidak mengakibatkan kepemilikan apapun. Tersedianya banyak pilihan perusahaan property penyediaan barang kebutuhan saat ini, merupakan tantangan bagi perusahaan-perusahaan proferty untuk menjawab tuntutan pelanggan yang tidak hanya berorientasi pada harga, tetapi juga tuntutan kualitas pelayanan yang sesuai dengan keiinginan konsumen yang melebihi harapan dan membuat konsumen merasa puas dengan pelayanan yang ada perusahaan tersebut.

Para pelaku bisnis saat ini menempatkan konsumen pada posisi sebagai mitra karena disadari olehnya bahwa kelangsungan bisnisnya sangat tergantung pada kepuasan konsumen. Maka dari itu wajib bagi perusahaan untuk memberikan pelayanan yang baik agar timbulnya kenyamanan dan kepuasan terhadap konsumen.

Dalam persaingan yang sangat ketat ini pada pasar property, dimana konsumen dihadapkan pada berbagai alternatif pilihan produk yang ditawarkan, maka produsen dituntun untuk selalu mengikuti perkembangan pasar sebagai dasar penetapan keputusan. Keberhasilan suatu keputusan memerlukan pemahaman tentang perilaku konsumen. kualitas pelayanan merupakan suatu masalah yang perlu perhatikan, sebab kualitas pelayanan dapat mempengaruhi pola pikir seseorang dalam mengambil keputusan dan kepuasan seorang konsumen.

Kepuasan konsumen adalah sejauh mana manfaat sebuah produk atau jasa dirasakan (perceived) sesuai dengan apa yang diharapkan konsumen. Konsumen akan puas apabila mendapat pelayanan yang berkualitas. Menurut Kotler (2008: 46) kepuasan konsumen adalah tingkat perasaan seseorang setelah membandingkan kinerja atau hasil yang ia rasakan dibandingkan dengan harapannya. Bila kinerja melebihi harapan mereka akan merasa puas dan sebaliknya bila kinerja tidak sesuai harapan maka akan kecewa.

Kepuasan konsumen dapat diartikan keinginan setiap perusahaan. Selain faktor penting bagi kelangsungan hidup perusahaan, memuaskan kebutuhan konsumen dapat meningkatkan keunggulan dalam persaingan. Konsumen yang puas terhadap produk dan jasa pelayanan cenderung untuk kembali membeli produk yang perusahaan jual.

Kualitas pelayanan ini merupakan komponen penting dalam upaya menciptakan kepuasan konsumen. Hal inilah yang juga di sadari oleh PT. Trijaya 
Lestari di Jakarta.

Berdasarkan uraian di atas, maka penulis tertarik melakukan penelitian dengan judul "Pengaruh Kualitas Pelayanan Terhadap Kepuasan Konsumen Pada PT. Trijaya Lestari di Jakarta".

\section{TINJAUAN PUSTAKA}

\section{Kualitas Pelayanan}

Menurut Kotler dalam Tjiptono (2019:59) menyatakan bahwa "Kualitas pelayanan adalah tingkat keunggulan yang diharapkan dan pengendalian atas tingkat keunggulan tersebut untuk memenuhi keinginan pelanggan".

\section{Kepuasan Konsumen}

Menurut Kotler dan Keller (2019:138), “Kepuasan merupakan perasaan seseorang akan kesenangan atau kekecewaan setelah membandingkan kinerja suatu produk yang dirasakan dengan harapan mereka. Jika kinerja tidak memenuhi harapan, pelanggan tidak puas dan jika kinerja sesuai dengan harapan maka pelanggan puas".

\section{METODE PENELITIAN}

\section{Populasi}

Yang dijadikan sebagai populasi dalam penelitian ini adalah responden yang berjumlah 100 responden PT.

Tabel 1. Hasil Analisis Descriptive Statistics

Descriptive Statistics

\begin{tabular}{ll|r|r|r|r} 
& N & Minimum & Maximum & Mean & Std. Deviation \\
\hline Kualitas Pelayanan (X) & 100 & 28 & 44 & 34.20 & 3.782 \\
\hline Kepuasan Konsumen (Y) & 100 & 29 & 49 & 38.37 & 4.230 \\
\hline Valid N (listwise) & 100 & & & & \\
\hline
\end{tabular}

Kualitas pelayanan diperoleh varians minimum sebesar 28 dan varians maximum 44 dengan ratting score sebesar 3,420 dengan standar deviasi 3,782. Skor ini termasuk pada rentang sakala 3,40 4,19 dengan kriteria baik atau setuju. Kepuasan konsumen diperoleh varians minimum sebesar 29 dan varians maximum 49 dengan ratting score sebesar 3,837 dengan standar deviasi 4,230. Skor ini termasuk pada rentang sakala 3,40 4,19 dengan kriteria baik atau setuju.
Trijaya Lestari di Jakarta

\section{Sampel}

Teknik pengambilan sampling dalam penelitian ini adalah sampel jenuh, dimana semua anggota populasi dijadikan sebagai sampel. Dengan demikian sampel dalam penelitian ini sampel yang digunakan berjumlah 100 responden.

3. Jenis Penelitian

Jenis penelitian yang dipakai adalah asosiatif, dimana tujuannya adalah untuk mengetahui atau mencari keterhubungan antara variabel independen terhadap variabel dependennya

\section{Metode Analisis Data}

Dalam menganalisis data digunakan uji validitas, uji reliabilitas, analisis regresi linier sederhana, analisis koefisien korelasi, analisis koefisien determinasi dan pengujian hipotesis.

\section{HASIL PENELITIAN}

\section{Analisis Deskriptif}

Pada pengujian ini digunakan untuk mengetahui skor minimum dan maksimum skor tertinggi, ratting score dan standar deviasi dari masing-masing variabel. Adapun hasilnya sebagai berikut:

\section{Analisis Kuantitatif}

Pada analisis ini dimaksudkan untuk mengetahui pengaruh variabel independen terhadap variabel dependen. Adapun hasil pengujian sebagai berikut:

\section{a. Analisis Regresi Linier Sederhana}

Uji regresi ini dimaksudkan untuk mengetahui perubahan variabel dependen jika variabel independen mengalami perubahan. 
Adapun hasil pengujiannya sebagai

berikut:

Tabel 2. Hasil Pengujian Regresi Linier Sederhana

Coefficients ${ }^{a}$

Unstandardized

Coefficients

\begin{tabular}{lr|r|r|r|r} 
Model & \multicolumn{1}{c}{$\mathrm{B}$} & Std. Error & Beta & \multicolumn{1}{c}{$\mathrm{t}$} & Sig. \\
\hline 1 (Constant) & 8.237 & 2.394 & & 3.440 & .001 \\
\hline Kualitas Pelayanan $(\mathrm{X})$ & .881 & .070 & .788 & 12.660 & .000 \\
\hline
\end{tabular}

a. Dependent Variable: Kepuasan Konsumen $(\mathrm{Y})$

Berdasarkan hasil pengujian pada tabel di atas, diperoleh persamaan regresi $Y=8,237+0,881 X$. Dari persamaan tersebut dijelaskan sebagai berikut:

1) Konstanta sebesar 8,237 diartikan jika kualitas pelayanan tidak ada, maka telah terdapat nilai kepuasan konsumen sebesar 8,237 point.

2) Koefisien regresi kualitas pelayanan sebesar 0,881, angka ini positif artinya setiap ada

Tabel 3. Hasil Pengujian Koefisien Korelasi Kualitas Pelayanan Terhadap Kepuasan Konsumen.

\section{Correlations $^{\mathrm{b}}$}

\begin{tabular}{|c|c|c|c|}
\hline & & $\begin{array}{c}\text { Kualitas } \\
\text { Pelayanan }(X) \\
\end{array}$ & $\begin{array}{c}\text { Kepuasan } \\
\text { Konsumen (Y) } \\
\end{array}$ \\
\hline \multirow[t]{2}{*}{ Kualitas Pelayanan (X) } & Pearson Correlation & 1 & $.788^{* *}$ \\
\hline & Sig. (2-tailed) & & .000 \\
\hline \multirow[t]{2}{*}{ Kepuasan Konsumen (Y) } & Pearson Correlation & $.788^{* *}$ & 1 \\
\hline & Sig. (2-tailed) & .000 & \\
\hline
\end{tabular}

**. Correlation is significant at the 0.01 level (2-tailed).

b. Listwise $\mathrm{N}=100$

Berdasarkan hasil pengujian diperoleh nilai korelasi sebesar 0,788 artinya kualitas pelayanan memiliki hubungan yang kuat terhadap kepuasan konsumen. peningkatan kualitas pelayanan sebesar 0,881 point maka kepuasan konsumen juga akan mengalami peningkatan sebesar 0,881 point.

\section{b. Analisis Koefisien Korelasi}

Analisis koefisien korelasi dimaksudkan untuk mengetahui tingkat kekuatan hubungan dari variabel independen terhadap variabel dependen. Adapun hasil pengujian sebagai berikut: 
sebesar 37,9\% dipengaruhi oleh faktor lain yang tidak dilakukan penelitian.

\section{d. Uji Hipotesis}

Pengujian hipotesis dengan uji

Tabel 5. Hasil Uji Hipotesis Kuali $\mathrm{t}$ digunakan untuk mengetahui hipotesis mana yang diterima.

Rumusan hipotesis: Terdapat pengaruh yang signifikan kualitas pelayanan terhadap kepuasan konsumen.

\begin{tabular}{|c|c|c|c|c|c|}
\hline \multirow[b]{3}{*}{ Model } & \multicolumn{2}{|c|}{ Coefficients ${ }^{\mathrm{a}}$} & \multirow{3}{*}{$\begin{array}{c}\text { Standardized } \\
\text { Coefficients } \\
\text { Beta } \\
\end{array}$} & \multirow[b]{3}{*}{$\mathrm{t}$} & \multirow[b]{3}{*}{ Sig. } \\
\hline & \multicolumn{2}{|c|}{$\begin{array}{l}\text { Unstandardized } \\
\text { Coefficients }\end{array}$} & & & \\
\hline & $\mathrm{B}$ & Std. Error & & & \\
\hline 1 (Constant) & 8.237 & 2.394 & & 3.440 & .001 \\
\hline Kualitas Pelayanan $(X)$ & .881 & .070 & .788 & 12.660 & .000 \\
\hline
\end{tabular}

a. Dependent Variable: Kepuasan Konsumen (Y)

Berdasarkan hasil pengujian pada tabel di atas, diperoleh nilai $\mathrm{t}$ hitung $>\mathrm{t}$ tabel atau $(12,660>1,984)$, dengan demikian hipotesis yang diajukan bahwa terdapat pengaruh yang signifikan atara kualitas pelayanan terhadap kepuasan konsumen diterima.

\section{PEMBAHASAN HASIL PENELITIAN}

1. Kondisi Jawaban Responden Variabel Kualitas Pelayanan

Berdasarkan jawaban responden, variabel kualitas pelayanan diperoleh ratting score sebesar 3,420 berada di rentang skala 3,40 - 4,19 dengan kriteria baik atau setuju.

\section{Kondisi Jawaban Responden Variabel Kepuasan Konsumen}

Berdasarkan jawaban responden, variabel kepuasan konsumen diperoleh ratting score sebesar 3,837 berada di rentang skala 3,40 - 4,19 dengan kriteria baik atau setuju.

\section{Pengaruh Kualitas Pelayanan} Terhadap Kepuasan Konsumen

Kualitas pelayanan berpengaruh signifikan terhadap kepuasan konsumen dengan persamaan regresi $\mathrm{Y}$ $=8,237+0,881 \mathrm{X}$, nilai korelasi sebesar 0,788 atau memiliki hubungan yang kuat dengan kontribusi pengaruh sebesar 62,1\%. Pengujian hipotesis diperoleh nilai $\mathrm{t}$ hitung $>\mathrm{t}$ tabel atau
$(12,660>1,984)$. Dengan demikian hipotesis yang diajukan bahwa terdapat berpengaruh signifikan antara kualitas pelayanan terhadap kepuasan konsumen diterima.

\section{KESIMPULAN DAN SARAN}

\section{Kesimpulan}

a. Variabel kualitas pelayanan diperoleh ratting score sebesar 3,420 berada di rentang skala 3,40 - 4,19 dengan kriteria baik atau setuju.

b. Variabel kepuasan konsumen diperoleh ratting score sebesar 3,837 berada di rentang skala 3,40 - 4,19 dengan kriteria baik atau setuju.

c. Kualitas pelayanan berpengaruh signifikan terhadap kepuasan konsumen dengan persamaan regresi $\mathrm{Y}=8,237+0,881 \mathrm{X}$, nilai korelasi sebesar 0,788 atau kuat dan kontribusi pengaruh sebesar $62,1 \%$ sedangkan sisanya sebesar 37,9\% dipengaruhi faktor lain. Uji hipotesis diperoleh nilai $\mathrm{t}$ hitung $>\mathrm{t}$ tabel atau $(12,660>1,984)$.

\section{Saran}

Berdasarkan hasil penelitian di atas, maka penulis memberikan saran sebagai berikut:

a. Diharapkan kualitas pelayanan yang sudah baik terus dipertahankan dan ditingkatkan supaya konsumen bisa merasa puas. Perusahaan lebih menerima 
masukan dari konsumen sebagai bahan pertimbangan untuk mengembangkan lagi produknya sehingga pilihan yang tersedia pun semakin banyak dan beragam.

b. Perusahaan diharapkan bisa memberikan informasi yang jelas dan lebih menarik serta memperluas distribusinya agar konsumen bisa dengan mudah mendapatkan produk dan tempatnya pun harus cukup strategis atau mudah di jangkau oleh konsumen. Perusahaan harus lebih memperhatikan apa yang sedang diminati oleh konsumen sehingga bisa memenuhi kebutuhan konsumen yang berbeda-beda dan supaya konsumen bersedia untuk melakukan pembelian ulang dan tidak membeli di tempat lain.

\section{DAFTAR PUSTAKA}

Algifari. (2015). Analisis Regresi untuk Bisnis dan Ekonomi. Yogyakarta: BPFE.

Arikunto, Suharsimi (2014). Prosedur Penelitian Suatu Pendekatan Praktek. Jakarta: Rineka Cipta.

Bashu Swastha dan T. Handoko (2015) Manajemen Pemasaran Moderen, Yogyakarta: BPFE.

Basu Swastha Dharmmesta. (2014). Manajemen Pemasaran. BPFE: Yogyakarta. Buchari Alma. 2014. Manajemen Pemasaran dan Pemasaran Jasa. Edisi Revisi.

Bilson Simamora (2016) Panduan Riset Prilaku Konsumen, Jakarta: PT. Gramedia Pustaka.

Fandy Tjiptono (2017), Serivce Quality and Satisfiation. Jakarta: Edisi tiga. Andi.

Freddy Rangkuti (2016) Strategi Promosi Yang Kreatif, Edisi Pertama, Cetakan Pertama Jakarta: Gramedia Pustaka Utama.

Imam Ghozali (2017). Aplikasi Analisis Multivariate Dengan Program SPSS. Edisi Kelima. Semarang: Badan Penerbit Undip.

Istijanto (2014). Riset Sumber Daya Manusia. Jakarta: PT. Gramedia Pustaka
Kharis, Ismu Fadli (2011). Studi Mengenai Impulse Buying dalam Penjualan Online. Semarang : Skripsi Universitas Diponegoro

Kotler dan Amstrong (2017), Prinsip-prinsip Pemasaran. Edisi Kedua Belas". Jilid Satu. Jakarta: Erlangga.

Lupiyoadi (2016) Manajemen Pemasaran Jasa, Edisi 4, Jakarta: Salemba Empat.

Nurjaya, N., et al. (2021). The Effect of Product Promotion and Innovation Activities on Marketing Performance in Middle Small Micro Enterprises in Cianjur. Budapest International Research and Critics Institute (BIRCIJournal): Humanities and Social Sciences, 4(1), 528-540.

Philip Kotler (2017) Manajemen Pemasaran, Edisi Keempat Belas, Jakarta: PT. Indeks.

Phipil Kotler dan Kevin Keller (2017) Manajemen Pemasaran, Edisi Kedua Belas, Jilid Satu, Jakarta: Erlangga.

Rao, Purba, (2012). Measuring Consumer Perceptions Through Factor Analysis. The Asian.

Santoso, Singgih (2015). Menguasai Statistik Multivariat. Jakarta: PT Elex Media Komputindo.

Setiawati, N. P. A., et al. (2021). Effect of Technology Acceptance Factors, Website Service Quality and Specific Holdup Cost on Customer Loyalty: A Study in Marketing Departement of Packaging Industry. Annals of the Romanian Society for Cell Biology, 12685-12697.

Sudjana (2014). Metode Statistika, Bandung: Tarsido.

Sugiyono (2017). Metode Penelitian Administrasi: dilengkapi dengan Metode R \& D. Bandung: Alfabeta. 